\title{
PENGARUH MOTIVASI EKONOMI, GENDER, PERSEPSI DAN LINGKUNGAN KELUARGA TERHADAP MINAT MAHASISWA BERKARIR MENJADI AKUNTAN PUBLIK (STUDI EMPIRIS PADA MAHASISWA AKUNTANSI UNIVERSITAS SARJANAWIYATA TAMANSISWA YOGYAKARTA)
}

\author{
Yasinta Agatha Cahya \\ Fakultas Ekonomi \\ Universitas Sarjanawiyata Tamansiswa \\ e-mail : yasinta171197@gmail.com \\ Teguh Erawati \\ Fakultas Ekonomi \\ Universitas Sarjanawiyata Tamansiswa \\ e-mail : eradimensiarch@gmail.com
}

\begin{abstract}
This study aims to determine the effect of Motivation Economy, Gender, Perception and Family Environment towards students' interest in becoming a Public Accountant.

distributing questionnaires or questionnaires. Research sample This is an Accounting student at the University of Economics Faculty Sarjanawiyata Tamansiswa batch 2016-2018 which amounts to 100 respondents who have gone through audits 1 and 2 and passed. The sampling technique used purposive sampling. Tool analysis used Classical Assumption Test and Multiple Linear Regression Analysis Test. This study concludes that economic motivation is not affect career interest in becoming a public accountant, gender has no effect on career interest in becoming an accountant public, perception has a positive effect on career interest in becoming a public accountant and the family environment has no effect towards a career interest in becoming a public accountant.
\end{abstract}

\begin{abstract}
ABSTRAK
Penelitian ini bertujuan untuk mengetahui pengaruh Motivasi Ekonomi, Gender, Persepsi dan Lingkungan Keluarga terhadap Minat Mahasiswa menjadi Akuntan Publik. menyebarkan kuesioner atau kuesioner. Sampel penelitian ini adalah mahasiswa Akuntansi Fakultas Ekonomi Universitas Sarjanawiyata Tamansiswa angkatan 2016-2018 yang berjumlah 100 responden yang telah melalui audit 1 dan 2 dan dinyatakan lulus. Teknik pengambilan sampel menggunakan purposive sampling. Alat analisis yang digunakan Uji Asumsi Klasik dan Uji Analisis Regresi Linier Berganda. Penelitian ini menyimpulkan bahwa motivasi ekonomi tidak berpengaruh terhadap minat karir menjadi akuntan publik, jenis kelamin tidak berpengaruh terhadap minat karir menjadi akuntan publik, persepsi berpengaruh positif terhadap minat karir menjadi akuntan publik dan lingkungan keluarga tidak berpengaruh. menuju minat karir untuk menjadi akuntan publik.
\end{abstract}

Kata Kunci : Ekonomi Motivasi, Gender, Persepsi, Lingkungan Keluarga, Akuntan Publik. 


\section{Buletin Ekonomi}

\section{PENDAHULUAN}

Era yang semakin berkembang memberi peluang lapangan pekerjaan yang sangat beragam bagi setiap indivindu. Setiap individu dapat memilih untuk bekerja sesuai kemampuan yang dimilikinya. Banyaknya lulusan sarjana ekonomi khususnya di bidang akuntansi, menjadi peluang besar dalam mecari pekerjaan sesuai dengan bidangnya. Pendidikan yang memadai mendukung untuk menghasilkan mahasiswa lulusan jurusan akuntansi mendapatkan pekerjaan yang tepat dan sesuai dengan kemampuannya. Pendidik berkontribusi dalam menghasilkan lulusan yang berkualitas dan mampu bersaing dalam dunia kerja. Akuntan pendidik berperan sebagai simulator bagi para mahasiswa untuk mengarahkan dan memberikan pengetahuan mahasiswa untuk merencanakan dan menentukan karir pada mahasiswa.

Dalam dunia kerja ada beberapa profesi yang dapat dipilih oleh sarjana akuntansi diantaranya akuntan publik. Akuntan publik yaitu akuntan yang telah memeperoleh izin dari menteri keuangan untuk memberikan jasa akuntan publik di Indonesia, akan tetapi jumlah akuntan di Indonesia masih sangat minim. Padahal secara keseluruhan pengajaran akuntansi di perguruan tinggi lebih cenderung mengarahkan mahasiswanya untuk bekerja sebagai akuntan publik di Kantor Akuntan Publik (KAP). Minat mahasiswa untuk menjadi akuntan publik dan akuntan pemerintah dikatakan minim disebabkan sebagian besar mahasiswa lebih tertarik untuk menjadi akuntan perusahaan di sektor swasta. Disampaikan Wakil Menteri Keuangan Mardiasmo dalam peresmian Perpustakaan Riset Tata Kelola dan Akuntabilitas Keuangan Negara. Menurut Mardiasmo, dengan kondisi seperti itu harus ada kesiapan literasi terhadap keuangan negara bagi mahasiswa. Dikatakan bahwa pada sektor swasta mahasiswa yang mengambil sejumlah 400 orang dalam satu kelas. Sedangkan yang mengambil publik sector accounting atau government accountinghanya 15 sampai 20 orang, Mardiasmo di Gedung BPK RI, Kamis (28/6/2018).

Sebagai Mahasiswa Akuntansi Program S1 tingkat akhir tentunya mahasiswa sudah memikirkan dan menyiapkan karir apa yang nantinya akan ditempuh. Hal ini menjadi penting agar mahasiswa tidak salah dalam memilih karir. Mahasiswa akan dihadapkan pada berbagai jenis pilihan karir dan juga dipengaruhi oleh berbagai faktor, seperti motivasi dari dalam diri maupun dorongan dari keluarga atau adanya keinginan dan minat dalam bisang tersebut. Persepsi mahasiswa serta pengetahuan mahasiswa terkait dengan akuntan publik juga akan mempengaruhi keputusan mahasiswa dalam memilih karir. Minat mahasiswa dalam berkarir menjadi akuntan publik berhubungan dengan teori sosialisasi gender. Menurut Umar 2010 dalam dalam (Ari et al., 2017) teori sosialisasi gender laki-laki dan perempuan secara mendasar berbeda dalam perkembangan moral dan kecenderungannya membawa perbedaan nilai pada tempat kerja. Nilai, perilaku, dan sikap etis laki-laki dan perempuan adalah berbeda. Berdasarkan teori sosialisasi gender, laki-laki menempatkan nilai lebih pada uang, kemajuan, kekuasaan dan mengukur wujud dari kinerja perorangan. Menurut Bem (1981) gender merupakan karakteristik kepribadian seseorang yang dipengaruhi oleh peran gender yang dimilikinya dan dikelompokkan menjadi empat klasifikasi, yaitu maskulin, feminim, androgini dan tidak tergolongkan (Hapsoro, 2018).

Hubungan gender dengan minat mahasiswa dalam berkarir sebagai akuntan publik, peneliti mengacu pada penelitian yang dilakukan, yang menunjukkan bahwa gender adalah faktor yang mempengaruhi persepsi mahasiswa akuntansi terhadap pemilihan karir (Ari et al., 2017). Menurut Siagian (2012) dalam Suseno (2018) persepsi dapat dipahami dengan melihatnya sebagai suatu proses dimana seseorang mengorganisasikan dan menginterprestasikan kesan-kesan sensori dalam usahanya memberikan suatu makna tertentu kepada lingkungan. Interprestasi seseorang tentang kesan sensorinya mengenai lingkungannya akan sangat berpengaruh pada perilakunya yang pada gilirannya menentukan 


\section{Buletin Ekonomi}

faktor-faktor apa yang dipandangnya sebagai faktor motivasional yang kuat. Dalyono dalam Widyanti \& Saputra (2018) minat dapat timbul karena daya tarik dari luar, salah satunya lingkungan keluarga. Selain itu dalam menentukan karir yang akan dicapai tentunya mendapatkan dukungan dari lingkungan keluarga. Menurut Hasbullah (2005) dalam Santoso (2014) menyatakan bahwa lingkungan keluarga merupakan lingkungan pendidikan bagi anak yang pertama karena di dalam keluarga inilah anak pertama kalinya mendapatkan pendidikan dan bimbingan.

Menurut Ajzen dan Fishbain (1980) dalam Astasari (2018) teori perilaku terencana merupakan pengembangan dari The theory of reason action. Theory of Reason Action atau yang disebut dengan TRA merupakan teori yang berhubungan dengan minat berperilaku, didalamnya menjelaskan bahwa perilaku merupakan fungsi dari minat. Theory of Planned Behavior secara tidak langsung menunjukkan kemungkinan bahwa tidak semua perilaku dilakukan secara penuh dibawah kendali individu atau kelompok, maka kontrol perilaku yang yang dipersepsikan ditambahkan untuk mengatasi perilaku-perilaku tersebut.

Teori Hirarki Kebutuhan dikembangkan oleh Abraham Maslow. Maslow (1987) menjelaskan bahwa setiap orang terdapat sebuah hirarki dari lima kebutuhan. Kelima kebutuhan menurut Maslow yang diterjemahkan bebas sebagai berikut:

1. Physiological needs, kebutuhan seseorang akan makanan, minuman, tempat berteduh, seks dan kebutuhan fisik lainnya.

2. Safety needs, kebutuhan akan keamanan dan perlindungan dari kejahatan fisik dan emosional, serta menjamin bahwa kebutuhan fisik akan terus dipenuhi.

3. Love and belonging, kebutuhan akan kasih sayang, rasa memiliki, penerimaan dan persahabatan.

4. Esteem, kebutuhan akan faktor penghargaan internal seperti harga diri, otonomi, dan prestasi serta faktor penghargaan eksternal seperti status, pengakuan dan perhatian.

5. Self-actualization, kebutuhan akan pertumbuhan, pencapaian potensi seseorang dan pemenuhan diri serta dorongan untuk menjadi apapun yang diinginkan (Lukman \& Juniati, 2016).

Menurut teori sosialisasi gender yang dikemukakan oleh Betz 1989 dalam Astasari (2018). Menjelaskan bahwa laki-laki dan perempuan secara mendasar berbeda dalam perkembangan moral dan kecenderungannya membawa perbedaan nilai pada tempat kerja. Nilai, perilaku, dan sikap etis laki-laki dan perempuan adalah berbeda. Pria dan wanita menggambarkan dirinya sebagai equal mix dari sifat-sifat yang dipertimbangkan. Sifat yang dimiliki wanita, dikenal sebagai feminisme (agak tergugah, lemah lembut, emosional, patuh, sentimental, pengertian, perasaan iba, sensitif, dan ketergantungan). Sifat yang dimiliki pria, yakni Masculine (dokumen, agresif, pemberani, tegas, otoritik, analisis, kompetitif, dan mandiri). Dan gender neutural (adoptif, bijaksana, tulus hati, teliti, kompensional, dapat dipercaya, dapat diramalkan, sistematik, dan efisien).

Menurut Suseno (2018) gender adalah berbagai karakteristik yang berkaitan dengan, dan membedakan antara, maskulinitas dan feminitas. Karakteristik tersebut mengarah pada jenis kelamin secara biologi dimana maskulin adalah pria dan feminim adalah wanita. Dalam sosiologi, gender tidak hanya mengenai jenis kelamin, tetapi juga peran sosial dan identitasnya di dalam masyarakat.

Persepsi menurut Kamus Besar Bahasa Indonesia adalah tanggapan (penerimaan) langsung dari sesuatu atau merupakan proses seseorang mengetahui beberapa hal yang dialami oleh setiap orang dalam memahami setiap informasi tentang lingkungan melalui panca indera. Persepsi dapat diartikan sebagai proses kognitif yang dialami oleh setiap orang dalam memahami setiap informasi tentang lingkungannya melalui panca inderanya melihat, mendengar, mencium, menyentuh dan merasakan (Sari, 2013). 


\section{Buletin Ekonomi}

Menurut Prajanti (2015) dalam Dewi (2018) lingkungan keluarga merupakan kelompok sosial pertama dalam kehidupan manusia, tempat belajar dan menyatakan diri sebagai manusia sosial di dalam berinteraksi dengan kelompoknya. Lingkungan keluarga terutama orang tua berperan penting sebagai pengarah bagi masadepan anaknya, sehingga secara tidak langsung orang tua juga dapat mempengaruhi minat terhadap pekerjaan bagi anak di masa yang akan datang, termasuk mengarahkan untuk pilihan karir audit internal. Lingkungan keluarga merupakan wahana untuk mendidik, mengasuh dan mensosialisasikan anak, mengembangkan kemampuan seluruh anggota keluarga agar dapat menjalankan fungsinya di masyarakat dengan baik serta memberikan kepuasan dan menciptakan lingkungan yang sehat guna tercapainya keluarga sejahtera.

Menurut Ikbal (2011) dalam Agustina \& Yuli (2016) karir merupakan serangkaian kegiatan seseorang yang berhubungan dengan pekerjaan yang mengandung perilaku, kemampuan, sikap dan aspirasi selama hidupnya dimana hal tersebut memberikan arti dalam kehidupan. Karir seorang individu melibatkan rangkaian pilihan dari berbagai macam kesempatan.

Akuntan adalah sebutan dan gelar profesional yang diberikan kepada seorang sarjana yang telah menempuh pendidikan di fakultas ekonomi jurusan akuntansi pada suatu universitas atau perguruan tinggi dan telah lulus Pendidikan Profesi Akuntansi (PPAk) menurut Nugroho (2014).

Akuntan Publik merupakan akuntan yang telah memperoleh izin dari Menteri Keuangan untuk memeberikan jasa. Ketentuan mengenai akuntan publik ditur dalam Undang-Undang Nomor 5 tahun 2011 tentang Akuntan Publik dan Peraturan Menteri Keuangan Nomor 17/PMK.01/2008 tentang Jasa Akuntan Publik. Akuntan publik adalah akuntan profesional yang menjualkan jasanya kepada masyarakat umum, terutama dalam bidang pemeriksaan terhadap laporan keuangan yang dibuat oleh kliennya. Pemeriksaan tersebut terutama ditujukan untuk memenuhi kebutuhan para kreditur, investor, calon kreditur, calon investor, dan instansi pemerintah (terutama instansi pajak) Nugroho (2014).

Seorang akuntan publik akan memberikan jasa melalui Kantor Akuntan Publik (KAP). KAP merupakan badan usaha yang memperoleh izin dari Menteri Keuangan sesuai dengan peraturan Perundang-undangan. Dalam Undang-Undang Nomor 5/2011 tentang Akuntan Publik Pasal 3 ayat satu (1) dinyatakan bahwa jasa asuransi yang diberikan oleh akuntan publik meliputi:

1. Akuntan publik memberikan jasa asurans, yang meliputi:

a. jasa audit atas informasi keuangan historis,

b. jasa review atas informasi keuangan historis, dan

c. jasa asurans lainnya.

2. Jasa asurans sebagaimana dimaksud pada ayat (1) hanya dapat diberikan oleh akuntan publik. Selain jasa asurans sebagaimana dimaksud pada ayat (1), akuntan publik dapat memberikan jasa lainnya yang berkaitan dengan akuntansi, keuangan, dan manajemen sesuai dengan ketentuan peraturan perundang-undangan.

Pengaruh Motivasi Ekonomi terhadap minat berkarir menjadi akuntan publik

Motivasi ekonomi memiliki peran yang besar untuk menjadi akuntan publik untuk mendapatkan penghargaan finansial berupa gaji pokok, overtime atau lembur. Semakin tinggi motivasi ekonomi yang dimiliki mahasiswa maka akan berpengaruh terhadap minat menjadi akuntan publik.

Didukung oleh penelitian Husin (2015) bahwa motivasi ekonomi yang meningkat secara signifikan dapat meningkatkan minat mahasiswa akuntansi untuk mengikuti PPAk. Dengan demikian semakin tinggi motivasi ekonomi yang dimiliki mahasiswa maka akan 


\section{Buletin Ekonomi}

berpengaruh positif terhadap minat mahasiswa berkarir menjadi akuntan publik. Berdasarkan penjelasan diatas maka hipotesis penelitian ini adalah:

H1: Motivasi ekonomi berpengaruh positif terhadap minat berkarir menjadi akuntan publik Pengaruh Gender terhadap minat berkarir menjadi akuntan publik

Menurut Ernawati (2004) peran gender sangat penting dampaknya dalam tiap aktivitas yang dilakukan oleh manusia, dan dalam hal karir menjadi akuntan publik ini kadang orang berpandangan bahwa mungkin perempuan tidak terlalu bagus jika menjadi akuntan publik dilihat dari jenis pekerjaan yang dapat menyita waktu perempuan mengurus keluarganya (Astri Wulan Dary \& Ilyas 2017). Hal ini berbeda dengan yang diungkapkan oleh Law (2010) dalam Astri Wulan Dary \& Ilyas (2017) yang meneliti di Hongkong menyebutkan bahwa kebanyakan wanita yang memasuki profesi akuntan publik. Dengan demikian semakin tinggi pengetahuan peran gender maka akan berpengaruh positif terhadap minat mahasiswa berkarir menjadi akuntan pulik.

Berdasarkan penjelasan diatas maka hipotesis penelitian ini adalah:

H2: Gender berpengaruh positif terhadap minat berkarir karir menjadi akuntan publik.

Pengaruh Persepsi terhadap minat berkarir menjadi akuntan publik

Dalam penelitian yang dilakukan oleh Muhammadinah dan Efendi (2009) dalam Setya (2017) menunjukkan pandangan mahasiswa terhadap faktor persepsi dalam minat berprofesi. Dari penelitian menunjukkan bahwa mahasiswa yang memiliki persepsi yang baik mengenai profesi akuntan publik, maka hal ini dapat membentuk suatu minat mahasiswa untuk menjadi seorang akuntan publik. Sedangkan menurut Mulyaningsih (2016) persepsi mempengaruhi minat mahasiswa menjadi akuntan publik. Dengan demikian semakin tinggi wawasan dan pengalaman mahasiswa maka akan berpengaruh positif terhadap minat mahasiswa berkarir menjadi akuntan pulik.

Berdasarkan penjelasan diatas maka hipotesis penelitian ini adalah:

H3: Presepsi berpengaruh positif terhadap minat berkarir menjadi akuntan publik

Pengaruh lingkungan keluarga terhadap minat berkarir menjadi akuntan publik

Dengan ini dapat dikatakan bahwa keadaan lingkungan keluarga mahasiswa akuntansi sudah dikatakan baik, terutama pada perhatian orang tua dengan rata-rata indikator yang berupa komunikasi terjalin baik, orangtua memperhatikan kemajuan studi, orang tua menanyakan minat dan orangtua menjalin relasi untuk mencari lowongan pekerjaan. Begitupun dukungan orang tua dengan rata-rata indikator juga dinyatakan baik. Namun lain halnya dengan profesi yang ada dikeluarga hanya memperoleh rata-rata indikator yang berupa pertimbangan pekerjaan orang tua saat ini dan pertimbangan adanya anggota keluarga yang berprofesi sebagai akuntan publik. Dengan demikian semakin tinggi dorongan yang diberikan orang tua maka akan berpengaruh positif terhadap minat mahasiswa berkarir menjadi akuntan publik.

Berdasarkan penjelasan diatas maka hipotesis penelitian ini adalah:

H4: Lingkungan keluarga berpengaruh positif terhadap minat berkarir menjadi akuntan publik.

\section{METODE}

Variabel dependen yang digunakan dalam penelitian ini yaitu minat berkarir menjadi akuntan publik. Sedangkan variabel Independen dalam penelitian ini adalah motivasi ekonomi, gender, persepsi dan lingkungan keluarga. Populasi yang digunakan dalam penelitian ini adalah mahasiswa S1 Program Studi Akuntansi Fakultas Ekonomi Universitas Sarjanawiyata Tamansiswa. 


\section{Buletin Ekonomi}

Pemilihan sampel yang digunakan yaitu Mahasiswa S1 Akuntansi Fakultas Ekonomi Universitas Sarjanawiyata Tamansiswa angkatan 2016-2018 berjumlah 100 mahasiswa terdiri dari laki-laki dan perempuan yang sudah menempuh mata kuliah Pengauditan 1 dan Pengauditan 2 dinyatakan lulus. Teknik pengambilan sampel menggunakan teknik Purposive sampling. Metode analisis menggunakan uji kualitas data, uji asumsi klasik dan uji hipotesis menggunakan analisis regresi linear berganda.

\section{ANALISIS DAN PEMBAHASAN}

Menurut Pradana (2017) Analisis statistik deskriptif dilakukan dengan tujuan untuk memberikan gambaran (deskripsi) mengenai data penelitian supaya data yang tampilkan mudah dipahami dan informatif. Hasil analisis deskriptif ditunjukkan pada Tabel 1.

\begin{tabular}{|c|c|c|c|c|c|}
\hline \multicolumn{6}{|c|}{$\begin{array}{c}\text { Tabel 1 } \\
\text { Hasil Uji Statistik Deskriptif }\end{array}$} \\
\hline & $\mathbf{N}$ & Minimum & Maximum & Mean & Std. Deviation \\
\hline Total MAP & 100 & 36.00 & 80.00 & 59.5800 & 8.29528 \\
\hline Total ME & 100 & 11.00 & 30.00 & 21.5000 & 4.09113 \\
\hline Total GE & 100 & 15.00 & 30.00 & 23.5000 & 3.56895 \\
\hline Total PR & 100 & 31.00 & 60.00 & 44.8400 & 5.33280 \\
\hline Total LK & 100 & 35.00 & 65.00 & 51.3100 & 5.87873 \\
\hline Valid N (listwise) & 100 & & & & \\
\hline
\end{tabular}

\section{Sumber: Data Primer diolah, 2020}

Tabulasi data kuesioner dilakukan menggunakan Software Microsoft Excel 2007 dan diolah menggunakan program SPSS versi 21.0. Sebelumnya telah dilakukan uji pilot test dari 30 kuesioner yang dapat diolah pada penyebaran kuesioner tahap pertama menunjukkan bahwa semua butir pernyataan dinyatakan valid. Hal ini dibuktikan dengan nilai person correlatian > r-tabel dan nilai signifikannya < alpha yaitu 0,05 .

Uji Reliabilitas dilakukan menggunakan program SPSS Versi 21.0. Berdasarkan hasil SPSS yang dapat disimpulkan bahwa semua variabel dinyatakan reliabel. Hal ini dibuktikan dengan nilai Cronbach Alpha $>0.600$.

Pengujian normalitas data dilakukan untuk memenuhi persyaratan model regresi bahwa datayang diperoleh memiliki ditribusi normal. Hasil pengujian normalitas ditunjukkan pada Tabel 2. Berdasarkan tabel 2 dibawah, bahwa nilai Kolmogorov Smirnov $Z$ sebesar 1.109 dengan nilai signifikan (Asymp.s. 2-tailed) sebesar 0,171. Hal tersebut menunjukkan bahwa signifikan lebih dari 0,05 yang berarti residu terdistribusi secara normal sehingga memperkuat asumsi normal pada model regresi penelitian ini. 
Tabel 2.

Hasil Uji Normalitas

\begin{tabular}{ccr}
\hline & & Unstandardize d Residual \\
$\mathrm{N}$ & & 99 \\
\hline Normal Parameters ${ }^{\mathrm{a}, \mathrm{b}}$ & Mean & .0000000 \\
& Std. & 7.09985412 \\
& Deviation & \\
Most Extreme & Absolute & .111 \\
Differences & & \\
& Positive & .104 \\
& Negative & -.111 \\
Kolmogorov-smirnov Z & & 1.109 \\
Asymp. Sig. (2-tailed) & & .171 \\
\hline a. Test ditribution is Normal &
\end{tabular}

Sumber: Data Primer Diolah, 2020

Identifikasi ada atau tidaknya gejala korelasi antar variabel independen dan dependen. Apabila nilai Variance Inflation Factor (VIF) variabel tidak melebihi 10 dan nilai Tolerance lebih dari 0,10 maka model tersebut tidak terjadi multikolinearitas antar variabel independen. Hasil Uji Multikolinearitas pada Tabel 3.

Tabel 3

Hasil Uji Multikolinearitas

\begin{tabular}{ccc}
\hline Model & \multicolumn{2}{c}{ Colinerity Statistic } \\
& Tolerance & VIF \\
\hline TOTALME & 0,733 & 1,365 \\
TOTALGE & 0,711 & 1,406 \\
TOTALPR & 0,599 & 1,670 \\
TOTALLK & 0,726 & 1,377
\end{tabular}

Sumber : Data Primer Diolah, 2020

Berdasarkan Tabel 3 menunjukkan bahwa tidak terdapat hubungan multikolinearitas karena secara keseluruhan nilai VIF pada tabel kurang dari 10 dan nilai Tolerance tidak kurang dari 0,1 .

Uji heteroskedastisitas dilakukan untuk mengetahui atau tidak kesamaan variasi residual antara masing-masing pengamatan. Model regresi yang baik seharusnya tidak terjadi heteroskedastisitas. Uji ini dilakukan menggunakan uji Park dengan hasil pengujian sebagai berikut pada Tabel 4. Berdasarkan tabel 4 menunjukkan bahwa penelitian ini tidak terjadi masalah Heteroskedastisitas. Hal ini dibuktikan dengan nilai signifikan masing-masing variabel > 0,05 sehingga tidak terjadi Heteroskedastisitas. 


\section{Buletin Ekonomi}

Tabel 4.

Hasil Uji Heteroskedastisitas

\begin{tabular}{|c|c|c|c|c|c|c|}
\hline \multirow[t]{2}{*}{ Model } & & \multicolumn{2}{|l|}{$\begin{array}{l}\text { Unstandardized } \\
\text { Coefficients }\end{array}$} & \multicolumn{3}{|l|}{$\begin{array}{l}\text { Standardized } \\
\text { Coefficients }\end{array}$} \\
\hline & & & $\begin{array}{l}\text { Std. } \\
\text { Error }\end{array}$ & Beta & $\mathbf{t}$ & Sig. \\
\hline 1. & (Constant) & .006 & 2.310 & & 002 & .998 \\
\hline & TOTALME & -.123 & .063 & -.220 & -1.945 & .055 \\
\hline & TOTALGE & .135 & .074 & .209 & 1.818 & .072 \\
\hline & TOTALPR & .071 & .053 & .167 & 1.334 & .185 \\
\hline & TOTALLK & -.028 & .044 & -.073 & -.639 & .524 \\
\hline
\end{tabular}

a. Dependent Variabel : ABSRES2

Tabel 5.

Hasil Analisis Regresi Linear Berganda

\section{Unstandardirized}

Coefficient

\begin{tabular}{lrrrrr} 
Model & B & \multicolumn{2}{c}{ Std. Error } & & \multicolumn{2}{l}{$\begin{array}{l}\text { Standardi } \\
\text { zed } \\
\text { Coeffiients }\end{array}$} \\
\hline 1. (constant) & 18.212 & 7.673 & & 2.373 & Beta \\
TOTALME & .110 & .209 & .054 & .525 & .601 \\
TOTALGE & .094 & .246 & .040 & .384 & .702 \\
TOTALPR & .664 & .177 & .429 & 3.777 & .000 \\
TOTALLK & .134 & .146 & .095 & .924 & .358 \\
\hline
\end{tabular}
berikut:

Berdasarkan tabel 5 diperoleh persamaan regresi linier berganda dapat disusun sebagai

$$
\mathrm{Y}=18.212+0,110 \mathrm{X} 1+0,094 \mathrm{X} 2+0,664 \mathrm{X} 3+0,134 \mathrm{X} 4+\mathrm{e}
$$

Berdasarkan hasil uji persamaan regresi linear berganda dapat dilihat bahwa variabel independen yang paling dominan mempengaruhi minat mahasiswa berkarir menjadi akuntan publik pada variabel persepsi dengan nilai beta 0,664 .

Uji statistik t pada dasarnya untuk mengetahui pengaruh satu variabel independen secara individual dalam menerangkan variabel dependen secara signifikan. Jika probabilitas sig. $<0,05$ dan $t$ hitung $>\mathrm{t}$ tabel maka Ha didukung Ho tidak terdukung. Jika Probailitas sig. $>0,05$ dan $\mathrm{t}$ hitung $<\mathrm{t}$ tabel maka Ho diterima Ha menolak. Hasil uji statistik $\mathrm{T}$ terdapat pada tabel 6 . 
Tabel 6.

Hasil Uji Satistik T

\begin{tabular}{|c|c|c|c|c|c|c|}
\hline & \multirow[b]{2}{*}{ Model } & \multicolumn{2}{|c|}{$\begin{array}{l}\text { Unstandardized } \\
\text { Coefficients }\end{array}$} & \multirow{2}{*}{$\begin{array}{l}\text { Standardize } \\
\text { d } \\
\text { coefficients } \\
\text { Beta }\end{array}$} & \multirow[b]{2}{*}{$\mathbf{T}$} & \multirow[b]{2}{*}{ Sig. } \\
\hline & & B & $\begin{array}{l}\text { Std. } \\
\text { Error }\end{array}$ & & & \\
\hline \multirow[t]{5}{*}{1.} & (constant) & 18.212 & 7.673 & & 2.373 & .020 \\
\hline & TOTALME & .110 & .209 & .054 & .525 & .601 \\
\hline & TOTALGE & .094 & .246 & .040 & .384 & .702 \\
\hline & TOTALPR & .667 & .177 & .429 & 3.777 & .000 \\
\hline & TOTALLK & .134 & .146 & .095 & .924 & .358 \\
\hline
\end{tabular}

Sumber : Data Primer Diolah, 2020

a. Hipotesis 1: Motivasi Ekonomi (X1) terhadap Minat Berkarir menjadi Akuntan Publik (Y)

Berdasarkan tabel di atas menyatakan bahwa varaibel motivasi ekonomi mempunyai tingkat signifikan sebesar 0,601 dan t hitung 0,525. Berarti tingkat signifikan lebih besar dari $0,05(0,601>0,05)$ dan $\mathrm{t}$ hitung < t tabel $(0,525<$ 1,66088). Hal ini menyatakan H0 didukung dan H1 tidak terdukung. Dengan kata lain variabel motivasi ekonomi tidak berpengaruh terhadap minat berkarir menjadi akuntan publik.

b. Hipotesis 2: Gender (X2) terhadap Minat Berkarir menjadi Akuntan Publik (Y) Berdasarkan tabel di atas menyatakan bahwa variabel gender mempunyai tingkat signifikan sebesar 0,702 dan t hitung 0,384. Berarti tingkat signifikan lebih besar dari $0,05(0,702>0,05)$ dan $\mathrm{t}$ hitung $<\mathrm{t}$ tabel $(0,384<1,66088)$. Hal ini menyatakan $\mathrm{H} 0$ didukung dan $\mathrm{H} 2$ tidak terdukung. Dengan kata lain variabel gender tidak berpengaruh terhadap minat berkarir menjadi akuntan publik.

c. Hipotesis 3: Persepsi (X3) terhadap Minat Berkarir menjadi Akuntan Publik (Y)

Berdasarkan tabel di atas menyatakan bahwa variabel persepsi mempunyai tingkat signifikan sebesar 0,000 dan t hitung 3,777. Berarti tingkat signifikan lebih kecil $0,05(0,000>0,05)$ dan $t$ hitung $>\mathrm{t}$ tabel $(3,777>1,66088)$. Hal ini menyatakan bahwa H0 tidak terdukung dan H3 didukung. Dengan kata lain variabel Persepsi berpengaruh positif dan signifikan terhadap minat berkarir menjadi akuntan publik.

d. Hipotesis 4: Lingkungan Keluarga (X4) terhadap Minat Berkarir menjadi Akuntan Publik

Berdasarkan tabel di atas menyatakan bahwa variabel lingkungan keluarga mempunyai tingkat signifikan sebesar 0,358 dan $\mathrm{t}$ hitung 0,924 . Berarti tingkat signifikan lebih besar dari $0,05(0,358>0,05)$ dan $\mathrm{t}$ hitung $<\mathrm{t}$ tabel $(0,924<$ 1,66088). Hal ini menyatakan H0 didukung H4 tidak terdukung. Dengan kata lain variabel lingkungan keluarga tidak berpengaruh terhadap minat berkarir menjadi akuntan publik.

Koefisien determinasi $\left(\mathrm{R}^{2}\right)$ mengukur seberapa besar kemampuan model dalam menerangkan variasi variabel dependen. Pada penelitian ini uji koefisien determinasi $\left(\mathrm{R}^{2}\right)$ untuk menguji seberapa besar pengaruh variabel motivasi ekonomi, gender, persepsi dan lingkungan keluarga. Berikut ini uji koefisien determinasi $\left(\mathrm{R}^{2}\right)$. 
Tabel 7.

Hasil Uji Koefisien Determinasi $\left(\mathbf{R}^{2}\right)$

\begin{tabular}{lllll}
\hline Model & R & R Square & $\begin{array}{l}\text { Adjusted R } \\
\text { Square }\end{array}$ & $\begin{array}{l}\text { Std. Error of } \\
\text { The Estimate }\end{array}$ \\
\hline 1. & $.524^{\mathrm{a}}$ & .274 & .243 & 7.24934 \\
\hline \multicolumn{3}{c}{ Sumber : Data Primer Diolah, 2020} \\
\end{tabular}

Berdasarkan hasil uji koefisien determinasi tabel di atas diperoleh nilai Adjusted $\mathrm{R}$ Square sebesar 0, 243 artinya besarnya pengaruh dari motivasi ekonomi, gender, persepsi dan lingkungan keluarga terhadap minat berkarir menjadi akuntan publik $24,3 \%$. Sisanya sebesar $75,7 \%$ dipengaruhi oleh faktor-faktor lain yang tidak diamati dalam penelitian ini.

Berdasarkan hasil olah data menggunakan software SPSS 21.0, maka hasil pengujian hipotesis dapat dijelaskan sebagai berikut:

a. Pengaruh motivasi ekonomi terhadap minat berkarir menjadi akuntan public

Variabel motivasi ekonomi tidak berpengaruh terhadap minat berkarir menjadi akuntan publik kemungkinan disebabkan karena faktor dalam diri mahasiswa tersebut. Mahasiswa berfikir bahwa, jika mereka menjadi akuntan publik setidaknya akan mendapatkan gaji yang besar, kesejahteraan dan mendapatkan fasilitas dalam bekerja, namun dalam penelitian saya hasilnya negatif atau tidak terdukung. Mahasiswa lebih memilih untuk bekerja menurut apa yang mereka sukai sesuai kebutuhan dirinya sendiri maupun keluargannya.

Penelitian ini didukung dengan penelitian Ilmiha dan Syafrizal (2017) bahwa motivasi ekonomi tidak berpengaruh terhadap minat mahasiswa mengikuti pendidikan profesi.

b. Pengaruh gender terhadap minat berkarir menjadi akuntan publik

Variabel gender tidak berpengaruh secara signifikan pada minat berkarir menjadi akuntan publik. Kemungkinan minat berkarir baik pria maupun wanita sama-sama tidak terdapat perbedaan untuk memilih karir sebagai akuntan publik dan non akuntan publik.

Perbedaan hakiki menyangkut tentang gender memang tidak bisa diubah, namun perbedaan dalam peran gender dapat diubah berdasarkan faktor-faktor sosial dan sejarah. Gender tidak menjadi jaminan untuk bekerja dan menduduki jabatan yang tinggi, sehingga pencapaian karir dan jabatan berdasarkan kerja keras bukan berdasarkan gender.

Penelitian ini senada dengan penelitian yang dilakukan Lukman dan Djuniati (2019) bahwa gender tidak memiliki pengaruh yang signifikan terhadap pemilihan karir sebagai akuntan publik.

c. Pengaruh persepsi terhadap minat berkarir menjadi akuntan publik

Varibel persepsi berpengaruh positif dan signifikan terhadap minat berkarir menjadi akuntan publik. Disebabkan karena persepsi merupakan proses untuk menerjemahkan atau meninterpretasi stimulus yang masuk dalam indera. Maka mahasiswa akan terdorong untuk berpikir dan mengembangkan pengetahuan dan pengalaman yang dimiliki. Semakin tinggi pengetahuan dan pengalaman yang dimiliki mahasiswa maka semakin tinggi minat mahasiswa berkarir menjadi akuntan publik. Variabel ini senada dengan penelitian Santoso, (2014) yaitu persepsi berpengaruh signifikan terhadap minat menjadi akuntan publik. Menurut Pradana (2017) persepsi berpengaruh signifikan terhadap minat menjadi akuntan perusahaan.

d. Pengaruh lingkungan keluarga terhadap minat berkarir menjadi akuntan publik

Variabel lingkungan keluarga tidak berpengaruh signifikan terhadap minat berkarir menjadi akuntan publik. Kemungkinan lingkungan keluarga tidak berpengaruh signifikan disebabkan karena menurun atau meningkatnya dorongan dari lingkungan 


\section{Buletin Ekonomi}

keluarga yang tidak akan mempengaruhi seseorang dalam memilih karir. Variabel ini senada dengan penelitian Harianti (2017) bahwa lingkungan keluarga tidak berpengaruh signifikan terhadap minat menjadi akuntan publik. Berbeda dengan penelitian Santoso (2014) berpengaruh signifikan terhadap minat menjadi akuntan publik.

\section{KESIMPULAN}

Berdasarkan olah data dalam penelitian tersebut dapat disimpulkan bahwa:

a. Motivasi ekonomi tidak berpengaruh terhadap minat berkarir menjadi akuntan publik.

b. Gender tidak berpengaruh terhadap minat berkarir menjadi akuntan public

c. Persepsi berpengaruh positif terhadap minat berkarir menjadi akuntan public.

d. Lingkungan keluarga tidak berpengaruh terhadap minat berkarir menjadi akuntan publik.

\section{DAFTAR PUSTAKA}

Agustina, R., \& Yuli, J. (2016). Pengaruh Motivasi Terhadap Minat Mahasiswa Akuntansi di Banjarmasin Untuk Mengikuti Pendidikan Profesi Akuntansi. Jurnal Ekonomi Dan Bisnis, 9(2), 129-144.

Ari, K. B. J., Wahyuni, M. A., \& Sulindawati, N. L. G. E. (2017). Pengaruh Faktor Gender, Pertimbangan Pasar Kerja, Lingkungan Kerja, Penghargaan Finansial dan Pelatihan Profesional Terhadap Minat Mahasiswa dalam Berkarir Sebagai Akuntan Publik. EjournalS1 Ak Universitas Pendidikan Ganesha, 8(2). https://ejournal.undiksha.ac.id/index.php/S1ak/article/view/13589/8464

Astasari, A. (2018). Analisis faktor-faktor yang Mempengaruhi Minat Mahasiswa Akuntansimemilih Karir Sebagai Akuntan Publik. Skripsi Universitas Islam Yogyakarta.

Astri Wulan Dary, \& Ilyas, F. (2017). Pengaruh Gender, Penghargaan Finansial dan Pertimbangan Pasar Kerja Terhadap Minat Mahasiswa Akuntansi Untuk Berkarir Menjadi Akuntansi Publikasi dan Non Akuntansi Publik. Fakultas Ekonomi Dan Bisnis, Universitas Bengkulu, 7(1), 51-60.

Dewi, D. A. K. (2018). Persepsi Mahasiswa Akuntansi Terhadap Minat Mahasiswa Akuntansi Menjadi Auditor Internal. Skripsi.

Hapsoro, D. (2018). Analisis Faktor-Faktor yang Mempengaruhi Minat Mahasiswa Akuntansi Berkarir Sebagai Akuntan Publik ( Studi Kasus Terhadap Mahasiswa Akuntansi STIE YKPN Yogyakarta ). Program Studi Akuntansi, Fakultas Ekonomika Dan Bisnis, 2(2), 142-156. https://doi.org/10.29230/ad.v2i2.2638

Harianti, S. S. (2017). Pengaruh Penghargaan Finansial, Pertimbangan Pasar Kerja Dan Lingkungan Keluarga Terhadap Minat Menjadi Akuntan Publik (Studi Empiris Mahasiswa S1 Akuntansi Universitas Negeri dan Swasta Kota Padang). 1-29. file://C:/Users/Jessica/AppData/Local/Temp/2427-4906-1-SM.pdf

Husin, S. (2015). Pengaruh Motivasi Kualitas Dan Motivasi Ekonomi Terhadap Minat Mahasiswa Akuntansi Untuk Mengikuti Pendidikan Profesi Akuntansi (PPAK) Dengan Kepribadian Individu Sebagai Variabel Moderating. Jurnal Online Mahasiswa Fakultas Ekonomi Universitas Riau, 2(1), 1-15.

Ilmiha, J., \& Syafrizal. (2017). Pengaruh Motivasi Kualitas, Motivasi Karir dan Motivasi Ekonomi Terhadap Minat Mahasiswa Ikuti Pendidikan Profesi. E-Jurnal Riset Akuntansi 


\section{Buletin Ekonomi}

Multiparadigma, 4(3).

Lukman, H., \& Djuniati, C. (2019). Pengaruh Nilai Intrinsik, Gender, Parental Influence, Persepsi Mahasiswa dan Pertimbangan Pasar Kerja dengan Pendekatan Theory Of Reasoned Action Model Terhadap Pemilihan Karir sebagai Akuntan Publik Bagi Mahasiswa Perguruan Tinggi Swasta di Jakarta.

Lukman, H., \& Juniati, C. (2016). Faktor Yang Pengaruhi Pemilihan Karir Sebagai Akuntan Publik Bagi Mahasiswa PTS Swasta Dengan Pendekatan Reasoned Aaction Model. Jurnal Akuntansi, 20(2), 202-215. https://doi.org/10.24912/ja.v20i2.54

Mulyaningsih, M. (2016). Pengaruh Penerapan Undang-Undang Profesi Akuntan Publik Terhadap Minat Mahasiswa Menjadi Akuntan Publik (Studi Kasus Di Universitas Indonesia Dan Universitas Trisakti). JIAFE (Jurnal Ilmiah Akuntansi Fakultas Ekonomi), 2(2), 28-38. https://doi.org/10.34204/jiafe.v2i2.542

Nugroho, A. (2014). Analisis Faktor-Faktor Yang Mempengaruhi Minat Mahasiswa Akuntansi Untuk Berkarir Menjadi Akuntan Publik. NASKAH PUBLIKASI. http://eprints.ums.ac.id/29175/9/02._NASKAH_PUBLIKASI.pdf

Pradana, D. (2017). Pengaruh Motivasi Dan Persepsi Mahasiswa Tentang Pendidikan Profesi Akuntansi Terhadap Minat Menjadi Akuntan Perusahaan Pada Mahasiswa Akuntansi Fakultas Ekonomi Universitas Negeri Yogyakarta. Skripsi Universitas Negeri Yogyakarta.

Pratiwi, P. W. (2018). Analisis Pengaruh Motivasi Kualitas, Motivasi Karir, Motivasi Ekonomi, Biaya Pendidikan Dan Persepsi Pada Minat Mengikuti Pendidikan Profesi Akuntansi (PPAk). https://doi.org/10.1017/CBO9781107415324.004

Santoso, C. B. (2014). Pengaruh Lingkungan Keluarga, Motivasi Dan Persepsi Mahasiswa Tentang Profesi Akuntansi Publik Terhadap Minat Menjadi Akuntan Publik Pada Mahasiswa Program Studi Akuntansi Universitas Riau Kepulauan Batam. Jurnal Measurement, $8(1)$

4. https://www.journal.unrika.ac.id/index.php/measurement/article/view/199/195

Setya, D. (2017). Pengaruh Presepsi Terhadap Minat Mahasiswa Akuntansi Syariah Untuk Berkarir di Bidang Pajak (Studi Empiris Pada Mahasiswa Akuntansi Syariah). Journal of Chemical Information and Modeling. https://doi.org/10.1017/CBO9781107415324.004

Siwi, M. P. (2016). Pengaruh Motivasi Terhadap Minat Mahasiswa Akuntansi untuk Mengikuti Pendidikan Profesi Akuntan Publik (PPAk). Skripsi Sekolah Tinggi Ilmu Ekonomi Widya Wiwaha Yogyakarta, 1-95.

Suseno, N. S. (2018). Pengaruh Gender, Motivasi Eksternal Dan Internal Terhadap Persepsi Mahasiswa Akuntansi Dalam Memilih Karier Sebagai Akuntan Publik. Jurnal Komunikasi Hasil Pemikiran Dan Penelitian Program Studi Ilmu Komunikasi, Universitas Garut P-ISSN: 2461-0836; E-ISSN: 2580-538X, 4, 75-98.

Widyanti, R., \& Saputra, D. (2018). Pengaruh Penghargaan Finansial, Pertimbangan Pasar Kerja Dan Lingkungan Keluarga Terhadap Minat Menjadi Akuntan Publik. Menara Ekonomi ISSN, IV(2), 88-95. 